MICHAEL RIESSLER (Joensuu)

\title{
RIMMA KURUCH AND KILDIN SAAMI LANGUAGE PLANNING*
}

\begin{abstract}
Rimma Dmitrievna Kuruch (1938-2019) was the pioneer of language planning for Kildin Saami. Together with several native Saami co-workers, she worked out and described the rules defining the current orthographic standard, established teaching in primary schools and published the most comprehensive, up-to-date dictionary of Standard Written Kildin Saami.
\end{abstract}

A year ago, on July 8, 2019, the pioneer of Kildin Saami language planning and revitalization, Rimma Dmitrievna Kuruch (Римма Дмитриевна Куруч${ }^{1}$ ), passed away in Murmansk.

Rimma Kuruch was born in Balovo in the Vacha District of Nizhny Novgorod Oblast on May 6, 1936. Nothing is known to me about her childhood and schooldays. She studied Russian language and literature and English at the Alecu Russo State Pedagogical Institute of Bălți (today Alecu Russo State University of Bălți) in the former Moldavian SSR. In 1961, she graduated as a teacher and started working in village schools in Moldova, before taking up her pedagogical studies again. She defended her Candidate's Dissertation at the Institute for National Schools of the Academy of Pedagogical Sciences of the USSR (today Russian Academy of Pedagogical Sciences) in 1967 and started working as a researcher at Chernivtsi State University (today Yuriy Fedkovych Chernivtsi National University) in Ukraine in 1968. She became a docent at the same university in 1971, but moved to Murmansk in 1975. There, she started working as Head of the Department for Russian Language and Literature at Murmansk State Pedagogical University (today Murmansk Arctic State University). Later, she worked at Murmansk Higher Marine Engineer school (today Murmansk State Technical University).

Regrettably, several details about Kuruch's early career in Russian pedagogical sciences as well as the exact chronology of her affiliations in Murmansk are unknown to me. How she became interested in Saami studies is also unclear. According to historian Maksim Kuchinski (p.c., January 2020), Kuruch may have been officially delegated to work in Murmansk due to her specialization in Russian language teaching in nonRussian national schools and her practical experience while working in non-Russian speaking environments in Moldova and Western Ukraine. But I cannot rule out that she moved to Murmansk for some other, completely personal reasons. However, it is possible that it was the famous ethnologist and linguist Zakhari Chernyakov (1900-

* A Russian version of the obituary was published in Родной язык 2020 (1), 291229.

${ }^{1}$ See https://www.wikidata.org/wiki/Q12718004 with open bibliographic data, including links to Wikipedia and Wikimedia Commons. 
1997) who introduced Kuruch to the field of Saami studies in 1976 (see Кучинский 2012 : 84). As a statistician and language planner for ethnic minorities, Chernyakov surveyed various non-Russian speaking people across the Soviet Union. In connection to this research he visited the Kola Peninsula for instance in $1975 .^{2}$

1975 was also the year when Kuruch permanently settled in Murmansk. Only shortly thereafter, a working group (or 'author group', as it was called in Russian) for the development of Saami bilingual education was founded in the Murmansk Section for Minority Education. She was the head of this group, which included the Murmansk Oblast official for education Boris Glukhov (1923-2019) as well as two representatives of Saami intelligentsia, Aleksandra Antonova (1932-2014) and Oktyabrina Voronova (1934-1990), as collaborators (cf. Eek 1984). Antonova and Voronova had graduated from A. I. Herzen Leningrad State Pedagogical Institute (today Herzen State Pedagogical University of Russia) and gathered experience as teachers of Russian language and literature in the local context. In 1976, the working group officially introduced native language teaching at the so-called National Boarding School in Lovozero, where most local Saami families sent their children to and where Antonova was working as Headmistress. Kuruch herself describes how her pioneering research on Saami began:

”Когда в 1975 году я приехала в Мурманск [---] Как филолог, я видела, что дети, обучающиеся на русском, сохраняют в своем менталитете структуру родного языка, то есть думают-то они по-саамски. Тогда и собралась группа энтузиастов из саамской интеллигенции, которая начала работать над саамским алфавитом, букварем и словарем. [---] Когда мы начинали, вопрос возрождения и сохранения языков коренных малых народов не имел государственного звучания, но реальную поддержку мы находили.”3 (Денисенко 2003)

A relatively detailed description about how Saami education in Russia was established in the 1970s can be found in an article in the Finnish newspaper "Lapin kansa" from 1977 (Kurutsh 1977; reported also in Norwegian in Utvik 1985). It describes insights about bilingualism and bilingual education, which were rather novel, even in the Nordic Saami context. I therefore find it remarkable that some of the recent studies on Saami bilingualism and language revitalization in Russia fail to take adequate notice of Kuruch's role, and transpose the start of this work to a later time or attribute it to other main actors. A paper published in 2011, for instance, states that Kildin Saami revitalization started "in recent years". 4

Even if Antonova organized Saami study circles back in the early 1970s, and it was Chernyakov who introduced Kuruch and Antonova to each other, it was not before Kuruch's scientifically well grounded initiative that systematic institutionalized language planning for Kildin Saami start. The results of this initiative were substantial. Through creating a new alphabet for Kildin Saami, standardizing its use in accordance with the language's morphophonological rules and adapting the vocabulary to the needs of modern society, the most important requirements for effective c or pus planning were fulfilled. Furthermore, a c quisition plan$\mathrm{n}$ i $\mathrm{n} \mathrm{g}-$ aiming at the creation of teaching materials, educational methods and guidelines - was carried out in collaboration with governmental organizations. As opposed

${ }^{2}$ According to http://lexicon.dobrohot.org/index.php/ЧЕРНЯКОВ_Захарий_Ефимович.

3 'When I arrived in Murmansk in 1975 [---] I saw how [Saami] children learning Russian were keeping, in their own mind, the native language structure [---] So I collected a group of enthusiastic Saami intellectuals, who started working on the creation of a Saami alphabet, a primer and a dictionary. [---] When we started, questions about the revitalization and preservation of indigenous people did not find state backup, but we managed to find some practical support.'

4 "De senaste åren har en kildinsamisk revitaliseringsprocess startet i Lovozero." (Scheller 2015 [2011] : 476). 
to the intense but short-lived work with Saami language planning in the 1930s, which did not leave the Saami in the Soviet Union with sustainable results, the work by Kuruch and her collaborators continues to have an effect even today. Several recent language activists, teachers and writers of Kildin Saami (e.g. Ekaterina Mechkina (b. 1934), Nina Afanasyeva (b. 1939), Ekaterina Korkina (b. 1943), Elvira Galkina (b. 1965), in addition to the above mentioned Aleksandra Antonova) were affiliated with the working group or were otherwise involved in its work, gathering knowledge and experience. The relatively numerous literary texts and other materials distributed in print or online during the recent decade use the orthographic standard (or variants thereof) developed and anchored since 1975. All applied scientific initiatives currently working in collaboration with Kola Saami activists in the field of language planning use Kuruch's practical and theoretical achievements as groundwork.

Until the mid-1990s the Kildin Saami language planners working with Kuruch published a whole set of text books and didactic guidelines (for grades 1 through 3), literary texts and other materials. Among the latter is the comprehensive Kildin SaamiRussian dictionary (Антонова, Афанасьева, Глухов, Куруч, Яковлев, Мечкина 1985), of which Kuruch was the editor and one of the co-authors. It is this dictionary for which Kuruch is best known in the field of Saami linguistics. It was among the first comprehensive bilingual dictionaries for one of the contemporary written Saami standard languages (see also the reviews by Klaus (1987) and Bartens (1988)). None of the later Kildin Saami dictionaries by Kert (Керт 1986), Sammallahti and Hvorostuhina (1991) and Antonova (Антонова 2014) reach the lexicographic and grammatical consistency and descriptive significance of Kuruch's 1985 dictionary. In addition to the fields of education and lexicography, Kuruch also published works on Kildin Saami phonetics and morphology, wrote a sketch grammar and co-authored an extensive description of the principles underlying the Kildin Saami orthography and punctuation (Куруч, Афанасьева, Виноградова 1995).

Unfortunately, the working group led by Kuruch was disbanded in 1990. Various sources and contemporary witnesses mention the lack of administrative and financial support in the aftermath of the Soviet Union's collapse as the main reasons for terminating the group. According to Rantala (1994 : 202), Kuruch herself left the group for private business.

During the same period, the first Kola Saami political movements evolved. Kuruch's participation in these movements is not surprising given her enthusiasm as a scholar and Saami language worker and the intertwined connections between Kola Saami ethnic revival and language activism. In 1990, for instance, Kuruch was among the three official Saami delegates to the 2nd International Indigenous Women's Conference in Karasjok. Furthermore, she had an influential role during the establishment of the Kola Saami Association (described in more detail by Øverland and Berg-Nordlie (2012 : 94-95)), the first political organization of the Saami in Russia, which is a member organization of the Saami Council today. When the association was founded in 1989, Kuruch was even elected vice-president. Shortly thereafter, she was also involved in various Saami civil society activities (described in more detail by Øverland and Berg-Nordlie (2012 : 96-97)), which were viewed controversially by parts of Kola Saami society. Simultaneously, a conflict about the course of language planning polarized the Kola Saami, with Kuruch and her former co-worker Aleksandra Antonova as the most prominent antagonists. These conflicts were perhaps the main motivation for the Russian academic Kuruch to abandon Saami studies and start working in Russian political parties and civil organizations instead.

I became acquainted with Rimma Kuruch during my first fieldtrip to the Kola Peninsula in winter 2004. Nina Afanasyeva introduced us. I remember how the three of us drank tea in Kuruch's office in the cellar premises of the Party of Pensioners (Kuruch led the party's local committee in Murmansk) in Terskiy Pereulok street and discussed some questions I had about Kildin Saami morphology and syntax. 
Later, I met Kuruch occasionally or listened to speeches she gave during official Saami events or gatherings in Murmansk.

Despite her professional duties outside the Saami field, the former researcher continued to be active in Saami language work. She was already in contact with language technologists from Finland, Norway and the UK during the late 1990s, in order to lay the ground for future digital work with language planning. As a result, the Cyrillic Saami characters were added to the Unicode standard and new fonts were created specifically for printing Kildin Saami at the Saami publishing house Davvi Girji (Everson 1999; Кучинский 2012 : 92). Her driving force, according to her own statements to me and confirmed by Nina Afanasyeva and other of her former colleagues, was the urgent need for a comprehensive Russian-Kildin Saami dictionary. The lack of this resource, which was originally planned to be produced as the second dictionary by the working group, continues to have obvious consequences for teaching and using Kildin Saami today. This can be seen, for instance, in currently published literary texts and teaching materials produced by a new generation of authors and proof-readers who lack confidence in consistent spelling (cf., e.g., Альманах саамской литературы 2019).

Kuruch's latest concrete project initiative for establishing a new working infrastructure and finding material support for creating this dictionary was the founding of the Saami language laboratory at the Arctic Center for the Scientific Study and Expertise (an independent non-profit organization, which also published the dictionary by Antonova (Антонова 2014)) in Murmansk in 2015. Unfortunately, this project had no significant research outcome.

In 2010, the Russian Association of Indigenous Peoples of the North (RAIPON) awarded Rimma Kuruch the medal "За верность Северу" (For Loyalty to the North), recognizing her important work for the Saami people. Her achievements in the creation of Kildin Saami literacy and the establishment of native language education deserve appreciation and respect, even if some of her scientific decisions are sometimes questioned by a new generation of researchers in Saami studies.

\section{Kuruch's works on Kildin Saami (in chronological order)}

1977

R. K u r u t s h, Saamen kieli Neuvostoliitossa. - Lapin Kansa 25.08.1977, 4. 1981

Р. Д. К у р уч, О категории числа существительных в кильдинском диалекте саамского языка. - СФУ 1981 XVII, 266-272. 1983

A. E e k, R. D. K u r u č, Accoustic Measurements of Some Quantity Patterns in Kildin Lapp. - СФУ 1983 XIX, 16-23.

1985

R. D. K u ru č, Classes of Verbs in Lapp Language. - Congressus Sextus Internationalis Fenno-Ugristarum. Vol. III. Abstracts, Syktyvkar 1985, 53.

A. А. Ан тонов а, Н. Е. А Фана сьева, Б. А. Глухов, Р. Д. Куруч, Л. Д. Яковл ев, Е. И. М ечк и на, Саамско-русский словарь, Москва 1985.

Р. Д. К у р у ч, Краткий грамматический очерк саамского языка. - А. А. А нто но ва, Н. Е. А фан а сь ева, Б. А. Глухов, Р. Д. Ку руч, Л. Д. Я к о в л ев, Е. И. М ечк и на, Саамско-русский словарь, Москва 1985, 529-567.

1988

Н. Е. А ф а н а с ь е в а, Р. Д. К у р уч, Р. И. Я к о в л в а, Саамский язык. Разработки по саамскому языку для начальной школы, Мурманск 1988.

Р. Д. К у р уч, Дидактический раздаточный материал для учащихся 1-го класса, Мурманск 1990. 
Р. Д. К у р уч, Классы глаголов в саамском языке. - Материалы VI международного конгресса финно-угроведов. Том 2, Москва 1990, 113-115.

Р. Д. К у р у ч, Программа по саамскому языку для $1-2$ классов саамской национальной школы, Мурманск 1990.

Р. Д. Куруч, Н. Е. А фан а с ве в а, С. С. Леликов а, Е. И. Меч кина, А. Г. Х в оростухина, Р. И. Я ков лев а, Северное сияние. Саамский язык в картинках. Учебник по развитию речи в 1ом классе саамской школы, Мурманск 1990.

Р. Д. Куруч, Н. Е. А Фан а сьев а, Р. И. Я ков ле ва, Методическое руководство по обучению саамскому языку в начальной школе. Примерные поурочные разработки к учебнику саамскому языка для 1-го класса (часть I). Мурманск.

Р. Д. Куруч, Н. Е. А Фан а с в в а, Р. И. Я ковле ва, Методическое руководство по обучению саамскому языку в начальной школе. Примерные поурочные разработки к учебнику саамскому языка для 1-го класса (часть II), Мурманск 1990.

Р. Д. Куруч, Н. Е. А Фан а с в в а, Р. И. Я ков ле ва, Методическое руководство по обучению саамскому языку в начальной школе. Примерные поурочные разработки к учебнику саамскому языка для 1-го класса (часть III). Мурманск 1990.

Р. Д. Ку руч, Н. Е. А Фаннасьев а, Р. И. Я ковлев а, Е. И. М еч к и на, Методическое руководство по обучению саамскому языку в начальной школе (для 2-го класса), Мурманск 1990.

Р. Д. Ку руч, Н. Е. А фаннасьев а, Е. И. М ечкина, А. Г. Х во р о с т ух и на, Р. И. Я к о в л е в а, Саамский язык. Для 2-го класса саамской школы, Мурманск 1990.

1991

Р. Д. К у р у ч, Материал к учебнику саамского языка для второго класса саамской школы, Мурманск 1991.

Р. Д. К у р у ч, Методические рекомендации к занятиям по саамскому языку в 3-ем классе с программой и тематическим планированием, Мурманск 1991.

Р. Д. К у р у ч, Саамский алфавит. Разрезная азбука. Дидактический раздаточный материал к учебнику саамского языка для 2-го класса, Мурманск 1991.

Р. Д. Куруч, И. В. В и ноградов а, Р. И. Я ков ле в а, Саамскорусский и русско-саамский словарь для начальной саамской школы, Мурманск 1991.

Р. Д. Куруч, Е. И. Мечкина, Р. И. Яковлева, Н. Е. А фа н а с ь е в а, Саамский язык. Учебник для 3-го класса саамской школы, Мурманск 1991.

Р. Д. Куруч, Е. И. Мечкина, Р. И. Яковлева, И. В. Винно г р а д о в а, Н. Е. А фа н а с ь е в а, Олешек. Книга для дополнительного чтения в 3-ем классе саамской школы, Мурманск 1991.

Р. Д. Куруч, Р. И. Я ковлева, И. В. В иногр а дов а, Методическое руководство по обучению саамскому языку в III-ем классе, Мурманск 1991.

1995

Р. Д. Куруч, Н. Е. А фана сьева, И. В. В иноградова, Правила орфографии и пунктуации саамского языка, Мурманск 1995.

1998

Р. Д. Куруч, Н. Е. А фаннасьева, Е. И. Мечкина, А. Г. Хвор о с т ухина, Р. И. Я к о в ле в а, Саамский язык. Для 2-го класса саамской школы. Том 1 (переработанное), Мурманск 1998.

1999

Р. Д. Куруч, Н. Е. А фанасьева, Е. И. Мечкина, А. Г. Хвор ос т ухина, Р. И. Яко в ле в а, Саамский язык. Для 2-го класса саамской школы. Том 2 (переработанное), Мурманск 1999.

2009

Р. Д. Ку руч, Н. Е. А фан асьева, С. С. Леликова, Е. И. Мечкина, А. Г. Хворостухина, Р. И. Яков лева, Северное 
сияние. Саамский язык в картинках. Учебник по развитию речи в 1ом классе саамской школы (переработанное), Мурманск 2009.

\section{Address}

Michael Rießler

University of Eastern Finland

E-mail: michael.riessler@uef.fi

\section{R E F E R E N C E S}

B a r t e n s, R. 1988, [Review] Saamsko-russkij slovar. Pod redakciej R. D. Kuruč. Moskva: "Russkij jazyk" 1985. 567 S. - UAJb. Neue Serie. Band 8, $247-$ 249.

E e k, A. 1984, Probleme der lappischen Sprache und Kultur auf der Konferenz in Lujavr. - СФУ XX, 237-240.

E v e r s o n, M. 1999, When is a Descender not a Descender? Kildin Sámi Voiceless Consonants. Expert Contribution. https://web.archive.org/web/2012 0308152858/http://www.hum.uit.no/a/trond/kildinbackgr.pdf.

K 1 a u s, V. 1987, [Review] Саамско-русский словарь. Под редакцией Р. Д. Куруч, Москва, «Русский язык», 1985. 56 с.; Г. М. Керт, Словарь саамскорусский и русско-саамский. Пособие для учащихся начальной школы, Ленинград, «Просвещение», 1986. 247 с. - СФУ ХХІІІ, 145-149.

K u r u t s h, R. 1977 Saamen kieli Neuvostoliitossa. - Lapin Kansa 25.08.1977, 4.

$\varnothing$ ve r l a n d, I., B e r g-N o r d 1 i e, M. 2012, Bridging the Divides. Ethno-Political Leadership among the Russian Sámi, Oxford.

R a n t a l a, L. 1994, Samerna på Kolahalvön. Deras situation i dag. - JSFOu 85, 200-204.

S a m m a 11 a h t i, P., H v o r o st u h i n a, A. 1991, Unna sámi-saam' saam'sámi sátnegirjjáś, Ohcejohka.

S c h e 11 e r, E. 2015 [2011]), Samisk språkrevitalisering i Ryssland. Möjligheter och utmaningar. - Sápmi i ord och bild I. En antologi, Stockholm, 471-483.

U t v i k, U. K. 1985, Kolasamene. Fra tsarens undersåtter til sovjetiske borgere. MA thesis, Bergen.

Альманах саамской литературы, Москва 2019. http://kolanord.ru/html_public/ col_Kol-saamy/Aljmanah-saamskoj-litry_2019/.

Ан тонов а А. А. 2014, Саамско-русский словарь, Мурманск.

Антонова А. А., А фанасьева Н. Е., Глухов Б. А., Куруч Р. Д., Яко в л е в Л. Д., М ечк ин а Е. И. 1985, Саамско-русский словарь, Москва.

Д е н и с е н к о, Е. 2003, Саамские будни. - Эксперт Северо-Запад 21 (130). https://expert.ru/northwest/2003/21/21no-sobsh_51398/.

К е р т Г. М. 1986, Словарь саамско-русский и русско-саамский. Пособие для учащихся начальной школы, Ленинград.

К у ч и н с к и й М. Г. 2012, Проблемы преподавания саамского языка в Мурманской области. - Социолингвестическое состояние коренных малочисленных народов Севера, Сибири и Дального Востока Российской Федерации, Москва (Вестник Института образования малочисленных народов Севера, Сибири и Дального Востока Российской академии образования 1), 81-95.

Ку руч Р. Д., А фан а сь ева Н. Е., В иног радов а И. В. 1995, Правила орфографии и пунктуации саамского языка, Мурманск. 